\title{
The effect of physical effort on the psychological dimensions in the case of former athletes
}

\author{
Marin CHIRAZI'1, Irina ȘUBREDU²
}

\begin{abstract}
Starting from the theoretical assumptions regarding the fact that the sustained physical effort had repercussions on the mental dimensions and starting from the findings that I came across in practice regarding the fact that the mental state of the athletes varied in time during an endurance test, the aim of the present research was to investigate the effect of stress caused by sustained physical effort specific to endurance tests on the psychological dimensions - in the case of former athletes.

The attaining of the set goal was observed through a small scale experimental study case (two subjects of different age). They were involved in an endeavour for establishing a record for sailing the Danube in recreational kayaks provided with space for luggage; random accommodation. During that expedition, a series of mental characteristics of the participants were measured: emotional stability, anxiety level and degree of optimism. The research pointed out the different adaptive capacity of each individual, regardless of age, experience and personality.

Key words: adaptive, athletes, psychological parameters.
\end{abstract}

\section{Rezumat}

Pornind de la prezumţiile teoretice referitoare la faptul că efortul fizic susținut are ecouri asupra dimensiunilor psihice și de la constatările întâlnite în practică referitoare la faptul că starea psihică a sportivilor de performanță variază în timp pe parcursul unei probe de anduranță [1], cercetarea de față îşi propune ca scop investigarea efectului stresului cauzat de efortul fizic susținut specific probelor de anduranță asupra dimensiunilor psihologice la foștii sportivi de performanță. Atingerea obiectivului propus a fost urmărită prin intermediul unui studiu de caz experimental de scară redusă (cu doi subiecți de vârste diferite). Aceștia au fost implicați într-un demers de stabilire a unui record de parcurgere a Dunării în caiace de agrement, prevăzute cu spațiu pentru bagaje, cu cazare aleatorie. Pe parcursul acestei expediții, au fost măsurate o serie de trăsături psihice ale participanților: stabilitatea emoțională, nivelul de anxietate și gradul de optimism. Cercetarea a scos în evidență capacitatea diferită de adaptare a fiecărui individ, indiferent de vărstă, experienţă și tip de personalitate.

Cuvinte cheie: adaptare, sportivi, parametri psihologici.

\footnotetext{
1 Prof., “Alexandru Ioan Cuza” University, Iași, Romania, Faculty of Physical Education and Sport, e-mail: chirazim@yahoo.com

${ }^{2}$ Psychologist, Center for Educational, Psychological and for Persons with Special Needs Counseling , "Alexandru Ioan Cuza” University, Iasi, Romania
} 


\section{Introduction}

The participants to that study were two former athletes - age between 23 and 46 years old.

Those participants showed a series of common characteristics (both practiced combat sports, participated in the past to sports competitions, being accustomed to that type of stress, as well as the perseverance and the determination level necessary for attaining the performance goals; but there were also differences regarding the social standing (one of them was a student, while the other one was a professor at the same faculty) and the age (one of them had double the age of the other one), as well as the role (one initiated the action and the other one was the partner).

Regardless of those differences, both participants dealt with similar challenges during the expedition; in exchange, one of them self-assumed a higher degree of responsibility - both for the outcome of the expedition (setting a record for sailing the Danube) and for the physical and the psychological well-being of the team.

The participation of the subjects to that research was done based on their freely expressed consent, giving them the complete assurance of strict confidentiality and the fact that the results would be used exclusively for research purposes.

General goal: Study of the sustained physical effort specific to endurance tests on the psychological dimensions - in the case of former athletes.

Specific goals:

- study of the sustained psychical effort on the degree of optimism of the subjects;

- study of the sustained physical effort on the anxiety degree of the subjects;

- study of the sustained physical effort on the emotional stability of the subjects during the expedition;

- study of the variation of the effects of the sustained physical effort on the above-mentioned mental dimensions - depending on age comparatively.

\section{Methodology}

The participants to the present research undertook an endeavour to set a record for sailing the Danube in recreational kayaks provided with luggage space. Except for that goal, the participants monitored some somatic, physiological and biochemical parameters, the attaining of the physical limits, the development of the improvisation skills in order to solve some unpredicted situations.

Covering the distance of $2600 \mathrm{~km}$ took 29 days (about $90 \mathrm{~km} /$ day) without assistance from the shore and without any break. They paddled for about 12 hours, from 8 am to $8 \mathrm{pm}$. The position in the kayak was pretty uncomfortable (sitting down with the legs stretched out), the only movement that could be done was the semiflexion of the lower extremities.

Pain on the level of the lumbar area, the shoulders and the hands often occurred. The luggage space was limited and the participants also had monitoring equipment. The food could not be kept under the best conditions and that was the reason why the food was bought to last for 4-5 days. There was a permanent concern for rationalizing and supplementing the food reserves, as well as identifying the supply sources.

If during the day, the main inconveniences were the sun, the humidity, the muscle and the joint pains and the thirst, during the evening, there were the insects (mosquitoes), the poisonous plants (stinging nettles) and at night only the uncomfortable position due to the place where the tent was set up (it was hard to find a place where to set up the tent) and the amelioration of the irritations and the unsafety resulted from sleeping in a tent.

The main daily concerns were to identify the fastest watercourse, to cover a greater distance, to dose the effort and the reserves, to identify the place where to set up the tent and to carry out the tests.

The mental discomfort resulted from not ever knowing the depth of the water, the direction and the force of the surface and depth currents, the crossing point of the dams, getting the supplies, interacting with the authorities and other people.

From the physical point of view, the major pain was felt on the palms due to the pressure exercised on the paddle for a long time and the fact that the tissue did not have time to heal overnight because the duration of the sleep was 6-7 hours.

The physical and the mental state differed from one moment to the other. Thus, in the morning, between 8 am to $12 \mathrm{pm}$, the participants to the study were optimists, between $12 \mathrm{pm}$ to $3 \mathrm{pm}$, they were constantly searching for a discussion topic to draw the attention away from boredom and between 3 
pm and 5 pm, they were fighting against sleepiness, followed by a surprising mental and physical impetus. During that part of the day, they set the daily record for kilometres per hour and only the decrease of the light intensity made them stop for the night.

Both subjects lost weight, about 4-5 kilograms (from $75 \mathrm{~kg}$ ), but while A.V. (23 years old) lost weight constantly, M.C. (46 years old) slightly improved and then maintained his weight. In the end, there were modifications in the fatty tissue, at least regarding its location. Although the body weight decreased, the physical aspect did not suffer from major changes due to the fact that the muscle groups on the level of the torso toned up.

The physical effort was aerobic, the heart rate varied between 90 - 140 beats/minute, consuming 3500-4500 calories per day (parameters recorded by a special equipment).

The toughest moments were the crossing over a dam on the exit from Slovakia where the participants had to get out of the water under extremely difficult conditions, as well as at "Portile de Fier" ("Iron Gates") in Romania.

The longest days were the final ones (the last 5-6 days) because they could not control the distance anymore (the distance indicators were missing) and they did not know how many kilometers were left.

The communication between the two participants was good; most of the time was assigned to selfreflections.

The tests chosen for measuring the psychological dimensions were: temperament test (E.P.I. personality inventory), anxiety measurement test (S.T.A.I. Test x1) and a test for measuring the level of optimism (AASQ).

The reason for choosing those tests was, on the one hand, their soundness (they were recognized tools for their high fidelity and validity degree) and, on the other hand, the investigated mental dimensions (emotional stability, level of optimism and anxiety degree).

There were four moments for administering the tests: before the start of the expedition (V1), after 10 days (V2), after 20 days (V3) and at the end of the expedition (V4).

The subjects received the four sets of tools in closed envelops: the answer sheets together with the items and the instructions. The agreement was that after each test, the filled in answer sheets were put back into closed envelops, recording the date and the time of the test administration.

\section{Results}

The first analysis refers to the anxiety test.

A synthesis of the results of the anxiety test (S.T.A.I. - X1) is presented below in the following diagram (no. 1):

Diagram no. 1 Anxiety test

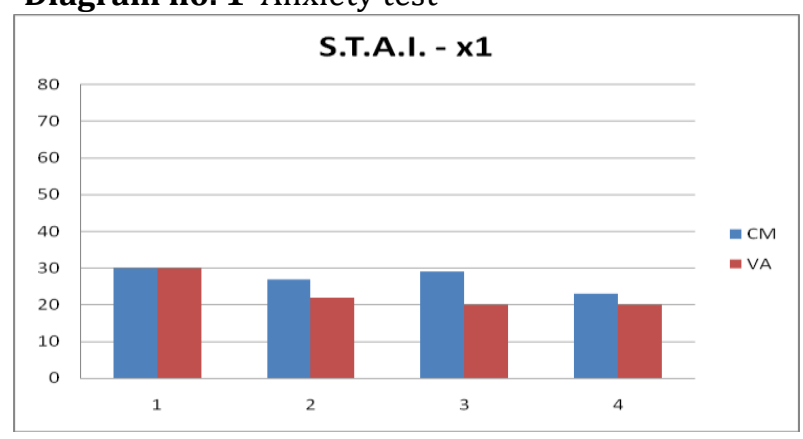

On the vertical, we have the scores obtained by the two participants to the study (CM, 46 years old and VA, 23 years old), and on the horizontal - the four test administrations. The obtained scores can range between 0 and 80 . We can notice that the higher scores are obtained during the first test administration (V1) - performed before starting the expedition and the lowest scores - the last test administration (V4) - performed at the end of the expedition. This can be explained based on a series of potentially harmful unknown factors that the participants would have to face.

There are also differences between the scores of the two participants: the scores obtained by $\mathrm{CM}$, the older participant are in general higher $(27$ - as compared to 22 - for the second test administration, 29 - as compared to 20 - for the third test administration, respectively 23 - as compared to 20 - for the last test administration). This can be explained by the fact that he assumed a greater responsibility regarding the outcome of the expedition (setting a new record), as well as the safety of the expedition.

The researches performed in the area of anxiety in the case of athletes [2, 3] have shown some reasons for this anxiety. These are: fear of failure, fear of negative assessments by others, fear of physical injury and fear of the unknown. 
We continue the presentation of the results with the analysis of the scores for the optimism measurement test.

A synthesis of the results for the ASQ test [4] is presented in the diagram from below (no 2):

Diagram no. 2 Scores for the optimism

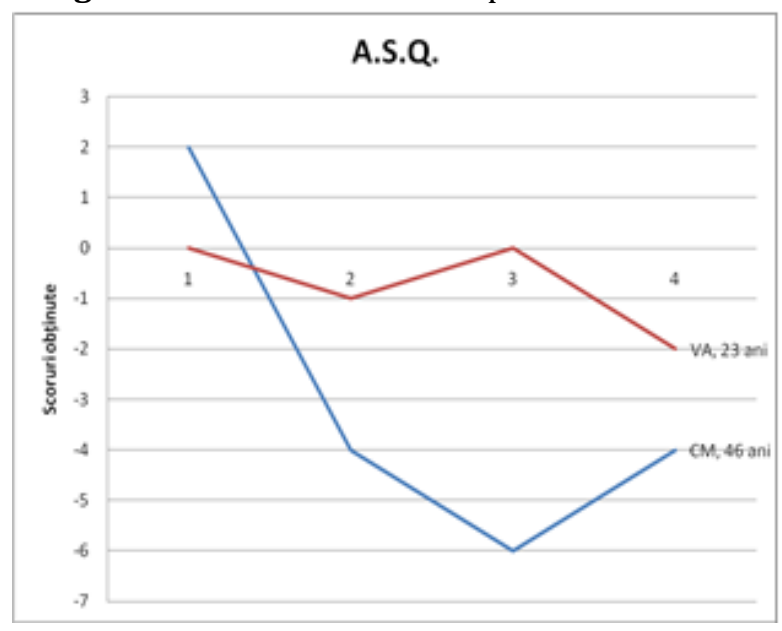

On the vertical, we have the scores obtained by the two participants to the study (CM, 46 years old and VA, 23 years old), and on the horizontal - the four test administrations. The obtained scores can range between -10.30 and 10.30 . We can notice that the higher scores are obtained - similar to the previous test - also for the first test administration (V1) performed before starting the expedition and then they begin to decrease. This can be possibly explained by the fact that upon the first test administration the participants could only imagine the amount of physical effort that they would deal with, as well as the obstacles that they would come across. Nevertheless, in the case of the rest of the test administrations - the participants were fully dealing with the effort and the challenges.

There are also big differences between the scores of the two participants. Thus, the scores obtained by $\mathrm{CM}$, the older participant are in general lower (- 4 as compared to 1 for the second test administration, 6 as compared to 0 for the third test administration, respectively 4 as compared to 2 for the last test administration) except for the initial measurement when the scores that he obtained were higher $(2$ as compared to 0 ). We can explain these differences by the fact that he assumed a greater responsibility which probably occurred at the start of the expedition.
The scores for this test also vary regarding their evolution in time in the case of the two participants, especially in the case of the measurements 3 and 4 . Thus, for the measurement 3 , the score obtained by CM (46 years old) decreases (recording the lowest value), the score obtained by VA (23 years old) increases, returning to the value recorded before the start of the expedition. In exchange, for the measurement 4 , the score obtained by CM ( 46 years old) slightly increases, while the score obtained by VA (23 years old) decreases, recording the lowest value during the entire expedition.

We continue the presentation of the results with the analysis of the scores for the for the irritability measurement test [5].

A synthesis of the results on the $\mathrm{N}$ scale within the E.P.I. test is presented in the following diagram (no. 3):

Diagram no. 3 Irritability measurement test

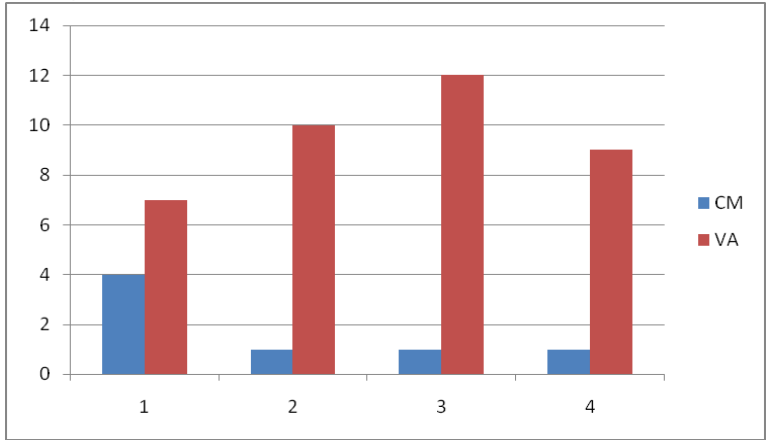

On the vertical, we have the scores obtained by the two participants to the study (CM, 46 years old and VA, 23 years old), and on the horizontal - the four test administrations. The obtained scores can range between 0 and 24. First of all, we can notice that the recorded scores are within the area of emotional stability (between 0 and 12) and not irritability (1224).

\section{Conclusions}

Further on, we must notice the big difference between the scores of the two participants to the study. Thus, the scores obtained by CM (the older participant) are much lower as compared to the scores of his teammate ( 4 as compared to 7 for the first test administration, 1 as compared to 10 for the second test administration, 1 as compared to 12 for the third test administration, respectively 1 as compared to 9 for the last test administration). This difference can be explained on the one hand due to 
the greater experience of the first participant that was more accustomed to physical effort and mental challenges resulted from the endeavour. On the other hand, we cannot completely exclude the hypothesis regarding the existence of an initial difference between the levels of emotional stability of the two participants which was accentuated during the expedition.

At the same time, the scores obtained by the two participants have a different evolution: in the case of the participant VA the level of the scores increases progressively for the second and the third test administration and then they decrease for the fourth test administration, while the level of the scores of the participant CM start to decrease after the beginning of the expedition and remain low until the end.

\section{References}

1. Timothy Ch., Mike C., Wray V. (2002). Sport and physical education. The Key Concepts, Second Edition, Routledge.

2. Levitt E. E. (1967). The psychology of anxiety, Bobbs-Merrill.

3. Moran A. (2004). Sport and Exercise Psychology, Routledge.

4. Seligman M. (2006). Learned optimism: how to change your mind and your life, Vintage Books.

5. Spielberger C. D. (1966). Theory and research on anxiety, in C. D. Spielberger (Ed.), Anxiety and Behaviour, (pp. 3-19). New York: Academic Press. 